[rh] High Performance Work Systems by Local Subsidiaries of Developed Country and Turkish MNEs and Indigenous Firms in Turkey

\title{
Adoption of High Performance Work Systems by Local Subsidiaries of Developed Country and Turkish MNES and Indigenous Firms in Turkey ${ }^{1}$
}

Mehmet Demirbag, Ekrem Tatoglu, and Adrian Wilkinson

\begin{abstract}
High performance work systems (HPWS) are seen as important in helping strengthen competitive strategies of multinational enterprises from developed countries (DC MNEs). Commensurate with global competitive pressures and internationalization strategies, emerging country MNEs (EC MNEs) and indigenous firms are also increasingly adopting HPWS. HPWS are not only seen as simply performance enhancing systems, but also as facilitators of internationalization. MNEs represent an important test bed for the HPWS and their applicability in different national contexts. In this paper, we contribute to the extant literature by focusing on HPWS adoption level within domestic subsidiaries of DC MNEs and EC MNEs along with stand alone indigenous firms in a single country setting by keeping the host country environment as constant.
\end{abstract}

Keywords: international HRM, high performance work systems, multinational enterprises, Turkey.

\section{Introduction}

The debate on convergence/divergence of management practices between multinational enterprise (MNE) affiliates and local firms is not new. Equally, the idea that different human resource management (HRM) practices are subject to different dynamics of convergence or divergence has also been around for several decades (Chen, Lawler, \& Bae, 2005; FentonO’Creevy, Gooderham, \& Nordhaug, 2008; Gooderham, Nordhaug, \& Ringdal, 1998; Pudelko \& Harzing, 2007; Sahadev \& Demirbag, 2011; Tregaskis \& Brewster, 2006). What is new however is the unprecedented growth in the number of emerging country MNEs (EC MNEs) and their desire to become global players. They have increasingly established their presence in developed countries and are setting up alliances with developed country MNEs (DC MNEs). We believe that the questions related to the convergence and divergence debate need to be re-formulated as EC MNEs are increasingly imitating (or according to some commentators copycatting DC MNEs) to become regional or global players (Chittoor, Sarkar, Ray, \& Aulakh, 2009; Luo, Sun, \& Wang, 
2011). Indeed, people management in acquired subsidiaries of EC MNEs in developed markets, emerges as a highly significant part of the integration or autonomy dilemma (Kale, Singh \& Raman, 2009). EC MNEs often try to adopt best management practices such as high performance work systems (HPWS) originating from more developed countries (Bartlett, Lawler, Bae, Chen, \& Wan, 2002; Chen et al., 2005; Guthrie, Liu, Flood, \& MacCurtain, 2008; Khavul, Benson, \& Datta, 2010; Madhook \& Keyhani, 2012). However, the evolution of institutions and the type of capitalism operating within the home countries of these EC MNEs may hinder or shape the effective introduction of HPWS, based within a liberal market context. It is argued that HPWS may be adapted into many different settings, but such systems are more likely to be sustained in contexts where there are strong complementarities (Wood \& Lane, 2012).

From a comparative perspective, there have been a number of studies comparing HRM practices of DC MNE subsidiaries and indigenous firms in their country of operation, though the results are mixed and difficult to interpret (Guthrie et al., 2008; Tregaskis \& Brewster, 2006) (for a more detailed account of comparisons between DC MNE subsidiaries and local firms see Mellahi, Demirbag, Collings, Tatoglu \& Hughes 2013). While HPWS are specifically identified by advocates of the divergence and convergence theses (Pudelko \& Harzing, 2007), neither specifically take EC MNEs into account in their arguments. Furthermore there have been several studies comparing HRM practices of DC MNE subsidiaries with those of local firms, however there is a clear paucity of research focusing on the convergence/divergence debate within the context of EC MNEs’ subsidiaries.

In this study, we seek to go a step further and examine HPWS adoption level amongst three different types of organizations, namely DC MNE subsidiaries, EC MNE subsidiaries and indigenous firms in Turkey. We specifically aim to examine similarities and differences by identifying the likelihood of adoption of individual HRM practices as components of HPWS. While models developed in this study do not establish causality between dependent and independent variables, we intend to contribute to the extant literature by focusing on HPWS adoption level within domestic subsidiaries of DC MNEs and EC MNEs along with stand alone 
indigenous firms in a single country setting, keeping the host country environment as constant for all three types of organizations. Therefore, this study examines people management aspects of domestic subsidiaries of EC MNEs in comparison to both DC MNE subsidiaries and indigenous firms in a key emerging country, Turkey. A focus on the possible adoption level of HPWS by these three types of organizations is also particularly important for: (i) theory contribution in terms of internationalization's effect on adoption level of HPWS by EC MNE subsidiaries; (ii) foreign investment firms seeking an entry to an EC market, and (iii) EC governments in developing training and education policies. Finally, the findings of this study will also assist EC MNE managers in understanding how best to adapt HPWS and benchmark their practices with DC MNEs.

\section{Literature Review and Hypotheses Development}

While there have been a plethora of studies examining HRM practices in an effort to identify convergence or divergence between MNE subsidiaries and local firms, more recent research suggests that sets of HRM practices are best treated as a system (Chen et al., 2005; Guthrie et al., 2008; Wright \& Bosewell, 2002) often described as "high performance work systems” (Wright \& Bosewell, 2002). The HPWS term is often used interchangeably with high involvement work systems (Lawler, 1986) and high commitment work systems (Legge, 2005). Zacharatos, Barling, and Iverson (2005) contend that HPWS encompass elements of both high involvement work systems (Bae \& Lawler, 2000; Guthrie, 2001) and high commitment work systems (Wood \& de Menezes, 1998). While there remains continued debate on a single set of HRM practices that comprise HPWS (Guest, 2011), in general HPWS include competence-based

performance appraisal, performance based compensation, internal communication, employee empowerment, alignment of HRM strategies with overall strategy, employee training and talent management programs (Marchington \& Wilkinson, 2012). It is argued that HPWS influence employees' abilities and motivation and are considered as important factors in determining workforce productivity, innovation and firm performance (Chen et al., 2005; Guthrie et al., 2008; Huselid, 1995; Minbaeva, Pedersen, Björkman, Fey \& Park, 2003; Tregaskis, Daniels, Glover, 
Butler, \& Meyer, 2013). HPWS and practices associated with these systems are most likely to be subject to forces driving their convergence (or divergence) when operating in an international context, and thus, the reason for our examination of HPWS in particular.

\section{Convergence/Divergence}

From a theoretical point of view, studies on HPWS adoption by MNE subsidiaries and local firms fall into three broad streams of literature. The first mainly focuses on the impact of HPWS on organizational outcomes without paying much attention to the organization's context. This body of literature has been labeled as the universal approach (Delery \& Doty, 1996) and fits with the convergence thesis (Bartlett et al., 2002; Chen et al., 2005; Fenton-O’Creevy et al., 2008; Pudelko \& Harzing, 2007; Rowley \& Benson, 2002). The convergence hypothesis suggests that best practices in management can be applied in different settings irrespective of cultural and institutional differences (Sahadev \& Demirbag 2011). This notion is derived from Kerr, Dunlop, Harbison and Myers's work (1960) in which they argue that the factors such as economic rationality, globalization of businesses and spread of technology increase convergence of management systems and practices in general (Kerr et al., 1960; Levitt, 1983; Rowley \& Benson, 2002). The convergence argument suggests that ongoing globalization of economic activities and competitive pressures to adopt optimally efficient solutions increasingly frees up management practices from the influence of institutions (Fenton-O’Creevy \& Wood, 2007; Gooderham et al., 1998; Guthrie et al., 2008; Pudelko \& Harzing, 2007). From this perspective, globalization is a powerful force which decreases diversity in HRM practices between nations, and therefore between MNEs and local firms (Demirbag, Collings, Tatoglu, Mellahi \& Wood, 2014; Sahadev \& Demirbag, 2011). This argument takes its theoretical underpinning from a transaction cost paradigm seeing firms striving for optimally efficient solutions leading to similar practices in different parts of the world (Fenton-O’Creevy \& Wood, 2007). This is a powerful argument for the convergence hypothesis as it is relevant to the decisions made by MNEs on the extent of centrally coordinated HRM practices (Fenton-O’Creevy \& Wood, 2007; Pudelko \& Harzing, 
2007). In short, advances in technology and communications are creating a less differentiated world order, where differences in management practices which had been perpetuated by geographic isolation of businesses are superseded by the logic of technology; hence management practices would be expected to converge globally (Kidger, 1991).

Insights from institutional theory suggest that organizations will increasingly resemble each other if not from a "common logic of industrialism” but a need to secure legitimacy (Barry \& Wilkinson, 2011; McGaughey \& DeCeiri, 1999; Wilkinson, Wood, Deeg, 2014). Previous studies provide some empirical evidence supporting this contention for DC MNEs, with the HRM function showing signs of convergence to the US dominant model regardless of context (Pudelko \& Harzing, 2007).

The extant literature on knowledge transfer and reverse knowledge transfer among MNE subsidiaries also advocates an increased level of convergence when knowledge is transferred and implemented by MNE subsidiaries (Björkman, Fey \& Park 2007; Mäkelä \& Brewster, 2009; McGuinness, Demirbag \& Bandara, 2013 Minbaeva, 2008; Minbaeva et al., 2003; Morris \& Snell, 2011; Taylor, Beechler \& Napier, 1996). The basic premise behind this argument is that as MNEs exploit their capabilities in international markets, and if HRM practices are effective in one location, then these can be shared with other subsidiaries within the MNE network (Björkman et al., 2007; Morris \& Snell, 2011). The counter argument is that these resources may be immobile; therefore there may be limited potential for the imitation or duplication of resources by other subsidiaries within the network (Morris \& Snell, 2011; see Jensen \& Szulanski (2004) for a more detailed discussion). The resource immobility argument leads to a proposal that MNE subsidiaries may not stand out as being more advantageous than local firms. This therefore runs counter to the idea of exploiting ownership specific advantages. These two ends of the discussion highlight a tension between internal and external fit for MNEs’ HRM systems. It emerges from these two sides of the argument that a HRM system needs to address the tension between local responsiveness (external fit) and global integration (internal fit). The external fit requires the generation of capability at a local level, which will be a source of competitive advantage. It is 
argued that this might actually diminish MNE performance at a global level unless these practices become more standardized and economies of scale achieved (internal fit). Non-transferred HRM capabilities and knowledge may lead to MNE subsidiaries re-inventing practices which may have been implemented by other units within the MNE network (Morris \& Snell, 2011; Taylor et al., 1996). Based on differentiation and integration arguments, Taylor et al. (1996) posit that MNE's HRM system orientation is also an important determinant of the level of HPWS transfer. While an adaptive approach requires a limited level of transfer, an exportive orientation requires a wholesale transfer, while an integrative orientation aims to create a worldwide system (Bartlett \& Ghoshal, 1986, 1988) that addresses the dual need for integration and differentiation. Therefore, as Bartlett and Ghoshal (1988) and Schuler, Dowling and De Cieri (1993) postulate, MNEs tend to address these two tensions simultaneously. The dual need for integration and differentiation increases the knowledge flow or transfer of HRM practices and hence convergence occurs between MNE subsidiaries. However, while there may be difficulties associated with knowledge flow between HQ and subsidiaries, Szulanski (1996) argues that the effectiveness of sharing or transferring knowledge between subsidiaries hinges on subsidiaries' ability to learn from other subsidiaries or the parent firm itself (see also Gupta \& Govindarajan, 2000; Szulanski, 1996).

Other commentators point out the increasing dominance of the US business schools along with the growth in the number of management consultancy firms in the creation and dissemination of new management knowledge accelerating convergence in management practices between MNEs and domestic firms (Fenton-O’Creevy \& Wood, 2007; Pudelko \& Harzing, 2007; Rowley \& Benson, 2002; Smith \& Meiksins, 1995).

The second stream of literature, the divergence approach, is based on criticism of the universal approach’s failure to take the context in which HRM practices are deployed (Delery \& Doty, 1996). The divergence hypothesis emphasizes the embeddedness of management systems in their cultural and institutional context (Pudelko \& Harzing, 2007; Tregaskis \& Brewster, 2006). It draws both from institutional theory (Whitley, 2000) including some varieties of capitalism arguments (Hall \& Soskice, 2001; Whitley, 2000), and also on culturist arguments (Hofstede, 
1980; House, Hanges, Javidan, Dorfman, \& Gupta, 2004). Both culturists and institutionalists see limited scope for convergence of management practices between nations (Fenton-O'Creevy et al., 2008; Pudelko \& Harzing, 2007). Despite an increase in the global integration between nations and industries, the European approach to institutions identify multiple reasons preventing convergence of management practices between nations (Gooderham et al., 1998; Hall \& Soskice, 2001; Tregaskis \& Brewster, 2006; Whitley, 2000) (see Fenton-O’Creevy et al., 2008; FentonO’Creevy \& Wood, 2007; Wood \& Lane, 2012 for a review and more detailed argument on this). The most important argument is based on path dependence of institutional evolution and institutional configurations (Guthrie et al., 2008; Whitley, 2000) which is seen to create national variations in terms of governments, regulations, culture and education systems, and thus variations in HRM practices. It should be noted that there is a broad difference between the US and European version of the institutional approach, in that while the US-based literature uses institutional arguments for convergence, in the European approach institutions are often used to explain enduring differences or even divergence in national practices (for a more detailed exposition see Demirbag et al., 2014; Fenton-O’Creevy et al., 2008; Fenton-O’Creevy \& Wood, 2007; Mellahi et al., 2013).

More recent literature however abandons the dichotomy of convergence vs. divergence argument by depicting a more differentiated picture. For instance, neo-institutional theory acknowledges both rational economic choices and legitimization decisions that managers have to make (Fenton-O’Creevy \& Wood, 2007). Thus, Fenton-O’Creevy and Wood (2007) argue that organizations adopt similar practices through competitive isomorphism. On the one hand organizations face pressures to be consistent with their external institutional environment, on the other hand they have a tendency to copy what is done elsewhere either to eliminate the legitimacy gap or close the capability gap that may emerge between themselves and their competitors.

Competitive isomorphism forces managers to make similar rational choices in similar competitive environments. Institutional isomorphism, however, emerges in three different types (coercive, mimetic and normative) which are described to cause an organization to alter its 
structure and conform to an institutional pattern (DiMaggio \& Powell, 1983; Rosenzweig \& Nohria, 1994). At an organizational level, however, it is argued that these isomorphic pulls influence a MNE's desire to standardize their HRM polices vis-à-vis the requirement to localize these policies or adapt them to local conditions (see Pudelko \& Harzing, 2007, p. 538). Collings, Lavelle and Gunnigle (2011) thus see MNEs as potential forces of revitalization and innovation on a global scale. They introduce the notions of adaptive innovation, defined as where the MNEs display a healthy regard for their host nations' HRM traditions and contrast such innovation with ‘disruptive innovation', an 'against-the-grain’ approach such as those famously deployed by US MNEs Wal-Mart and McDonalds. But as they note MNEs “do not operate in isolation from the environment around them but rather must organize their activities in the context of the multiple institutional environments in which they operate” (2011, p. 402) environments which are essentially intra-national. One of the main challenges relates to the institutional duality phenomenon where MNE subsidiaries need to maintain legitimacy in the eyes of their headquarters (HQ). This is achieved through implementing standardized HRM practices such as HPWS, while at the same time appearing as legitimate in the host country markets in which they operate, through adapting practices that account for local norms (Kostova \& Roth, 2002).

\section{EC MNEs}

When compared to DC MNEs, EC MNEs are not large in absolute terms, but many of these firms are diversified globally (Thite, Wilkinson \& Shah, 2012) and are becoming increasingly important actors particularly in their own triad-regions and in less developed regions such as Africa (Demirbag, Tatoglu and Glaister, 2010; UNCTAD, 2011). Their aspirations to play a greater role in global markets increasingly motivate them to adopt new management techniques (e.g. HPWS) to strengthen both their overseas and domestic subsidiaries (Chang, Wilkinson \& Mellahi, 2007, 2009; Khavul et al., 2010; Madhok \& Keyhani, 2012). Thus, there is an interest in the role of human resource investment in general and HPWS in particular for gaining competitive advantage in global markets. The same argument can also be extended to internationalization and 
success in reverse knowledge transfer by EC MNEs (Bae \& Lawler, 2000; Khavul et al., 2010). EC MNEs are late comers to global markets, with liability of emergingness and limited international experience (Guillen \& Garcia-Canal, 2009; Madhok \& Keyhani, 2012). Training and development of skills are important parts of their internationalization strategy as they have some distinct disadvantages in terms of human resource capability compared to DC MNEs (Khavul et al., 2010). While some EC MNEs have held alliances with DC MNEs for a long period of time (i.e., operating either as an original equipment manufacturer or a joint venture partner) (Demirbag, Mirza, \& Weir, 1995; Luo \& Tung, 2007; Ramamurti, 2012), others are at an early stage of internationalization, and hence are in need of more training and development activities to improve their "knowledge, skills and abilities" in these organizations. DC MNEs, however, use training and skill development component of HPWS to deliver measurable outcomes and improve employee motivation in their subsidiaries (Bartlett et al., 2002; Chen et al., 2005; Tregaskis et al. 2013). While EC MNEs have a dynamic pool of resources and the capability of deploying these resources to growth markets (Engardio, Arndt, \& Geri, 2006), their global operating system diverges from that of DC MNEs (Girod, Belin, \& Thomas, 2009; Wilkinson, Wood \& Demirbag, 2014).

The growing literature on EC MNEs appears to have some common ground with arguments developed from the neo-institutional perspective. Institutional theory posits that organizations have a tendency to replicate what is done elsewhere in an attempt to gain legitimacy or support of external agencies within a society (Strauss \& Hanson, 1997). When applied to EC MNEs, the neoinstitutional theory appears to explain their patterns of development and investment in HRM systems as well as their adoption of HPWS. EC MNEs are described as copycat and legitimacy seekers in their internationalization operations (Chittoor, Sarkar, Ray \& Aulakh, 2009; Luo et al., 2011). From the viewpoint of HRM system development, EC MNEs invest more heavily in HRM systems and development activities than local firms (Khavul et al., 2010). This is mainly due to capability deficits that EC MNEs face when competing in global markets (Madhok \& Keyhani, 2012). Thus, Guillen and Garcia-Canal (2009, p. 27) argue that international expansion for EC 
MNEs runs in parallel with a capability upgrading process to catch up with their more advanced competitors (see also Chittoor et al., 2009; Demirbag, Tatoglu, \& Glaister, 2009; Luo et al., 2011). From an institutional perspective, EC MNEs also face a legitimacy deficit as these firms are viewed by stakeholders in the developed countries as having lower safety and quality standards (Madhok \& Keyhani, 2012). Such perceptions coupled with capability concerns and competitive pressures force EC MNEs to adopt management practices that are widely considered as aiding to develop a human capital base and enhance organizational performance.

While there are clear differences between DC MNEs and EC MNEs, some commentators expect a convergence of these two groups. Ramamurti (2012) argues that DC MNEs and EC MNEs are at different stages of evolution, and in time EC MNEs may augment and enhance their ownership advantages to become more like DC MNEs (Lessard \& Lucea, 2009; Ramamurti, 2012). Further, Ramamurti (2012) posits that the observed differences in ownership advantages (capability to apply HPWS is seen as an ownership advantage) between DC MNEs and EC MNEs, and may reflect differences in their evolution rather than differences stemming from their country of origin. From an internationalization perspective, there is evidence that EC MNEs have a strong tendency to adopt practices associated with HPWS to support their internationalization strategy abroad (Bae \& Lawler, 2000; Girod et al., 2009; Khavul et al., 2010; Thite et al., 2012) as well as their business-level strategies in their domestic markets (Girod et al., 2009; Khavul et al., 2010).

\section{HPWS and EC MNEs - A Synthesis and Hypotheses}

While there have been a number of attempts to classify HPWS (Becker \& Gerhart, 1996; Boxall \& Macky, 2009; Greenwood, 2002; Guthrie, 2001; Jensen, Patel, \& Messersmith, 2011), there remains some inconsistency between these classifications with each emphasizing different aspects of HRM systems (see Boxall \& Macky, 2009 for a review). For instance, Bae and Lawler (2000, p. 503) argue that HRM systems can be observed on a continuum from high employee involvement (extensive training, high empowerment and broad job design/metrics) to low 
involvement (limited training, low participation and highly specialized jobs) HRM strategies. Dyer and Reeves (1995, p. 656) argue that HRM systems should be envisioned as "internally consistent bundles of human resource practices". HPWS, in this context, have been described as consisting of both hard and soft components of HRM systems (Arthur, 1994; Becker \& Gerhart, 1996; Delery \& Dotty, 1996; Huselid, 1995; Pfeffer, 1998).

Some theorists argue that HRM practices may be grouped into policy domains that are instrumental both in composition and effectiveness of HPWS (Lepak, Liao, Chung, \& Harden, 2006). They cluster around three groups of activities namely employee skills, motivation and empowerment. These three components of HPWS are implemented through a set of more specific HRM practices. As described by Lepak et al. (2006), employee training and talent management practices strengthen employees' competencies and skills thus can be linked to "knowledge, skills and abilities”. The second dimension put forward by Lepak et al. (2006) is related to employee's motivation to perform, hence being labeled as "motivation and effort". Practices that constitute the "motivation and effort" dimension of HPWS are more metric and measurement oriented, aiming to improve employee's motivation, and hence utilizes practices such as competence-based performance appraisal, and performance-based compensation. Lepak et al. (2006) argue that the third dimension of HPWS is more related to employee opportunity to perform and duly labeled as “opportunities to contribute”. The third component of HPWS thus constitutes the following practices such as employee empowerment, internal communication and teamwork. This three-part configuration captures both the soft and hard components of HPWS and fits well with the structure and environment in which both EC MNE and DC MNE subsidiaries operate.

Given there is no universal agreement on what constitutes HPWS, our selection of HRM practices for this study builds on Fey, Björkman and Pavlovskaya's (2000) list of HRM practices (see also Björkman et al., 2007; Minbeava, Pedersen, Björkman, Fey, \& Park, 2003). The practices selected emerge from a thorough review of the six most often studied HRM practices (Fey et al., 2000, p. 3). Thus, these practices appear as the most commonly utilized measures of HPWS in both the western context and emerging country settings (Chang et al., 2007, 2009; 
Minbaeva et al., 2003). Below we develop the hypotheses on DC MNE subsidiaries, Turkish MNEs’ domestic subsidiaries and indigenous firms' adoption level of HPWS in a key emerging country context, Turkey.

From a resource based perspective, HPWS include unique and inimitable resources which provide the firm with a competitive advantage (Barney, 1991). Therefore, their deployment by MNEs to their subsidiaries is an important component of firms' internationalization. The same argument applies to EC MNEs. Complexity of global markets and institutional environments in different locations forces both DC MNEs and EC MNEs to find a configuration of HPWS which balances the following three components, "knowledge, skills and abilities", "motivation and effort” and "opportunities to contribute” to benefit from the potential pay offs among them.

The choice to emphasize soft components or hard components is not a clear cut decision as there may be partial adoption of certain aspects. While firms can utilize multiple HRM strategies (Bae \& Lawler, 2000), in the case of EC MNEs there may be a tendency to adopt HPWS to accelerate their internationalization and be connected to their overall business strategy.

As noted earlier, the MNE represents an important testing ground for the HPWS and their applicability in different national contexts. A stream of literature points to the fact that HRM is recognized as an important facilitator for internationalization of firms (Girod et al., 2009; Glover \& Wilkinson, 2007; Khavul et al., 2010; Thite et al., 2012). There is also growing theoretical and empirical evidence, which tends to support the positive relationship between the deployment of HPWS and firm performance (Becker \& Huselid, 2009; Guthrie, 2001; Huselid, Jackson, \& Schuler, 1997). These factors combined with increases in the flow of knowledge from parent firms to subsidiaries and reverse knowledge transfer from subsidiaries to their parents imply that some convergence of HRM practices might be expected (Björkman et al., 2007; Demirbag et al., 2014).

Yet given that HPWS are based on Anglo-American oriented practices, it is less clear how HPWS will be applied and experienced in a different context. As Boxall and Macky (2009, p. 6) argue "some practices may well work in the Anglo-American world are understood quite 
differently and much less positively in less individualist or more hierarchical cultures”. Some writers argue that when EC MNEs and DC MNEs become more global, the difference between them may fade away (Pudelko \& Harzing, 2007) but this is by no means uncontested.

In line with an emerging body of theorizing which argues that MNEs are relatively insulated from external pressures for legitimacy, because their global standing means that they are generally in a position to promote new structures and practices rather than simply respond to pressures to adopt them (Kostova, Roth, \& Dacin, 2008), we expect HPWS to be effectively deployed in MNE subsidiaries in Turkey. We might expect that the "knowledge, skills and abilities" component of DC MNEs' HPWS in their Turkish subsidiaries may be particularly pronounced given the rapid pace of change in the Turkish economy and employees' attitudes towards training in the Turkish context. It has been argued that the young and educated workforce in Turkey have aspirations and preferences more aligned with their western counterparts (Aycan \& Fikret-Pasa, 2000). Further, we argue that those who choose to work in MNE subsidiaries are likely to be positively disposed towards HPWS. For instance, Aycan (2006) argues that training and skill enhancing programs are particularly important for MNEs as these are among the most motivating factors in Turkey. While EC MNEs are striving to close the capability gap with DC MNEs, due to being at a different level of internationalization and of evolution (Madhok \& Keyhani, 2012; Ramamurti, 2012), their “knowledge, skills and abilities" component of HPWS adoption level may be relatively less pronounced compared to DC MNE subsidiaries but higher than domestic firms. Based on these arguments we expect that:

Hypothesis 1a: The adoption level of "knowledge, skills and abilities" component of HPWS will be higher in DC MNE subsidiaries located in Turkey than that in both local subsidiaries of Turkish MNEs and indigenous firms in Turkey.

Hypothesis 1b: The adoption level of "knowledge, skills and abilities" component of HPWS will be higher in local subsidiaries of Turkish MNEs than in indigenous firms in Turkey.

While DC MNE subsidiaries implement standardized HPWS in different countries, they also need to maintain their legitimacy in host country markets; therefore they may need to adapt 
their practices to the local context (Kostova \& Roth, 2002). In deploying HPWS in emerging country markets, DC MNEs tend to emphasize measurement related components, as they routinely measure the quality of human resources and innovation processes as part of their performance systems (Girod et al., 2009). In general, DC MNE’s organizational culture heavily relies on hard components to emphasize and assure investors who are risk and uncertainty averse. These practices aim to control cost, compliance with rules and metrics including rewards based on business performance. Hard components in this context refer to utilitarian instrumentalism (Greenwood, 2002), where the aim is to gain competitive advantage by developing metric-based structures and performance and reward measures. Therefore, one would expect pay and performance related practices (i.e., "motivation and effort”) of HPWS to be adopted more highly in DC MNE subsidiaries compared to both local subsidiaries of EC MNEs and stand alone indigenous firms. Hence we posit that:

Hypothesis 2a: The adoption level of "motivation and effort" component of HPWS will be higher in DC MNE subsidiaries located in Turkey than that in both local subsidiaries of Turkish MNEs and indigenous firms in Turkey.

Hypothesis 2b: The adoption level of "motivation and effort" component of HPWS will be higher in local subsidiaries of Turkish MNEs than in indigenous firms in Turkey.

The "opportunities to contribute” component of HPWS aims at enhancing employees input and commitment to organization (i.e., engendering trust, involving employees in decision making and employee empowerment, and networking skills). While DC MNEs are more adept in transferring hard components of their HPWS to their subsidiaries, EC MNEs' distinct strength rests on the soft components of their HPWS (Girod et al., 2009). Although, in many aspects, EC MNEs still have a tendency to accumulate power in the centre due to their rapid internationalization needs, these organizations tend to use the soft components more than their counterparts in the developed countries. Thus, a recent study on EC MNEs' global operating systems highlights that their distinctive strength lies in their expertise in soft capabilities (Girod et al., 2009). One of the main characteristics of EC MNEs is that they are more flexible in 
subcontracting and outsourcing activities where they have no competitive edge. EC MNEs, by adopting HPWS, empower employees and provide them with more incentives to contribute than their rival firms (Luo et al., 2011, p. 47). Thus, facilitating the "opportunities to contribute" component of HPWS appears to be more pronounced in the subsidiaries of EC MNEs than those of DC MNEs and indigenous firms (Bae \& Lawler, 2000; Girod et al., 2009). This leads to the final two-part hypothesis.

Hypothesis 3a: The adoption level of "opportunities to contribute" component of HPWS will be higher in local subsidiaries of Turkish MNEs than that in both subsidiaries of DC MNEs and indigenous firms in Turkey.

Hypothesis 3b: The adoption level of "opportunities to contribute" component of HPWS will be higher in subsidiaries of DC MNEs than in indigenous firms in Turkey.

The conceptual framework and hypothesized relationships are summarized in Figure 1.

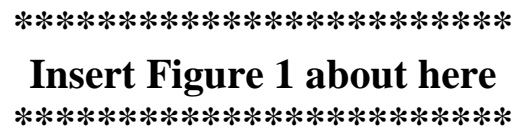

\section{Research Methods}

\section{Turkey as the Survey Setting}

We chose Turkey for this study for a number of reasons. Firstly, Turkey is the fastest growing economy in Europe and undoubtedly the leading economy in south-eastern Europe and the Middle East (Invest in Turkey, 2012). Secondly, Turkey represents a particularly interesting site for the consideration of HRM practices owing to the divergent 'socio-cultural contingencies' (Pudelko \& Harzing, 2007) evident there. As a close-knit society, the Turkish business context is typically characterized by large private industrial groups run by family members and professional managers (Gunduz \& Tatoglu, 2003), which is a dominant form of industrial organization in some other emerging countries such as India, Brazil and Mexico. Examination of HPWS within such a context with a research design including domestic firms and subsidiaries of Turkish MNEs 
as well as subsidiaries of developed country MNEs in Turkey enables us to draw conclusions for similar organizations in other emerging markets.

Over the last three decades, these large business organizations in Turkey have been increasingly involved in internationalization processes through exports while entering multiple joint ventures and strategic alliances with DC MNEs (Demirbag et al., 1995, 2009; Goksen \& Usdiken, 2001). Some of these conglomerates (such as Koc, Sabanci, Dogus, Eczacibasi and Ulker Groups) have also engaged in several cross border acquisitions and greenfield investments. Thus, Turkey provides an excellent context to examine how western HPWS are adopted by indigenous firms and firms which are more internationalized. Using the Turkish context will also enable us to extend our arguments to other emerging markets, particularly in those contexts where traditional values persist but a rapid internationalization of family owned groups is also evident.

While the presence of MNEs in Turkey dates back to pre-First World War, a significant surge in MNE operations was observed in the aftermath of the Second World War through the establishment of close relationships with the USA. Following the Marshall plan, the first legislation governing foreign direct investment (FDI) was enacted. The Mutual Security Agreement coupled with a gradual increase of MNEs from the USA facilitated know-how support and knowledge transfer to Turkey. According to Sayim (2011), Turkey has been a knowledge receiver country with a strong tradition of transferring knowledge and management practices from abroad. For instance, Usdiken and Wasti (2002) describe Turkey as a "receptive” country particularly with respect to HRM practices and management paradigms originating from the USA. Similarly, Ercek (2006) argues that Turkish firms institutionally have a habit of emulating and applying successful western managerial techniques in general and HRM practices in particular. Both Ercek (2006) and Iseri-Say, Toker and Kantur (2008) suggest that adoption of western managerial ideas at the firm level in Turkey is linked with the degree of their internationalization. Despite changes in internal and external institutions for firms operating in Turkey, Turkish firms are still characterized by centralized decision making, (Fikret-Pasa, 
Kabasakal, \& Bodur, 2001) prevalence of short term planning (Glaister, Dincer, Tatoglu, \& Demirbag, 2009) and powerful top-down leadership (Kabasakal \& Bodur, 2002). These organizational characteristics are likely to create difficulties for organizations in adopting new management ideas and techniques (Tanova \& Nadiri, 2005). On balance, while actors such as academia, internationalization of firms and management consultancies facilitate adaptation of western management ideas and techniques, the socio-cultural environment in Turkey is still markedly different from the western world, as it is a newly industrializing country with a society imbued with traditional and modern values (Glaister et al., 2009; Wasti, 1998). Therefore, the Turkish context provides a good testing ground for the mediation of internationalization on the diffusion of modernizing approaches to people management by EC MNEs in general.

Turkey, like many other developing economies, is characterized by both fluidity and intercoupling in institutional forms (see Wood \& Lane, 2012). Such an institutional context may provide a fertile ground for pioneering new practices or facilitating adoption of innovative approaches. On the other hand, adopted new practices may not necessarily be effective as within the original institutional environment where they were developed. Therefore, although findings of this study are specific to the Turkish context, these may serve as a basis for future comparative studies particularly aiming for the European periphery and other emerging countries with similar intuitional settings.

In short there is much to learn from the Turkish context. The characteristics of the Turkish economy and its strategic location as a bridgehead between East and West, taken together with the aforementioned contextual factors, make Turkey an excellent context to examine the nature of HPWS and to undertake a comparative study of the convergence/divergence link between subsidiaries of MNEs and indigenous Turkish firms.

\section{Sample and Data Collection}

The sampling frame for developed country MNE subsidiaries in Turkey was drawn from the database of a government agency, General Directorate of Foreign Investment (GDFI). All FDI 
firms operating in Turkey are recorded by the GDFI, which acts as a one-stop agency for implementing the regulations concerning FDI. As of June 2011, the database of GDFI consists of 27,444 FDI firms (GDFI, 2011). From this database, a new dataset was compiled based on the capital value of the subsidiary and the proportion of foreign equity shareholding. Those ventures with capital value of less than one million USD were excluded. Most of these firms are owned by a single person or established by means of ordinary partnerships. For the purposes of this survey, it was not considered feasible to include these firms in the sampling frame. The investments with foreign ownership of less than 10 per cent are considered to be portfolio investments and were also excluded from the database.

The sampling frames for both local subsidiaries of Turkish MNEs and indigenous firms in Turkey were drawn from the website of TOBB (The Union of Chambers of Commerce, Industry, Maritime Trade and Commodity Exchanges of Turkey, available at http://www.tobb.org.tr), which provides an industrial database that contains approximately 40,000 firms that are registered to any of 10 Chambers of Industry, 19 Chambers of Trade and 64 Chambers of Industry and Trade in Turkey.

Based on a random sampling selection procedure, a total of 500 firms for each group of DC MNE and Turkish MNE subsidiaries was generated and constituted the sampling frames for the subsidiaries of both DC and Turkish MNEs, respectively. Again, using a random sampling procedure, a total of 1000 firms was generated and constituted the sampling frame for indigenous firms in Turkey. A questionnaire and a cover letter were posted to the general manager of each subsidiary and indigenous firm with a letter requesting that the general manager, or his/her senior executive in charge of HRM within the organization, should complete it. For DC MNE subsidiaries, after one reminder, a total of 117 questionnaires were returned, of which 105 were usable (an effective response rate of 21 percent). For local subsidiaries of Turkish MNEs, a total of 92 questionnaires were returned following one reminder, of which 83 were usable (an effective response rate of 16.7 percent), while a total of 167 questionnaires were gathered after one reminder, of which 153 were usable (an effective response rate of 15.3 percent). All three 
response rates were satisfactory, given the nature of the questionnaire and the type of potential respondent.

A test for non-response bias for the mail survey was conducted by comparing the first wave of survey responses to the last wave of survey responses (Armstrong \& Overton, 1977). Almost 50 percent of the surveys were randomly selected for each of the first and last waves of the questionnaires received, and t-tests were performed on the survey responses. The test results indicated no significant differences in the responses between early and late respondents $(p>.10)$ for the following independent variables used to measure various components of HPWS: employee training $(t$-value $=.01, p=.99)$, competence-based performance appraisal $(t$-value $=.13, p=.89)$, performance-based compensation (t-value $=1.04, p=.29)$, employee empowerment $(t$-value $=$ $1.34, p=.16), \mathrm{HRM}$ and strategy fit $(t$-value $=.43, p=.66)$ and internal communication $(t$-value $=$ $.18, p=.86)$. Chi-square and t-tests were also used to compare the respondent firms with nonrespondent firms across the main characteristics of the sample such as industry type $\left(\chi^{2}=7.20, p=\right.$ $.21)$, firm size ( $t$-value $=.06, p=.95)$ and geographical location $\left(\chi^{2}=2.07, p=.36\right)$, and again showed no systematic differences $(p>.10)$, therefore no response bias was evident.

The characteristics of the questionnaire respondent firms for each group of sample firms are summarized in Table I.

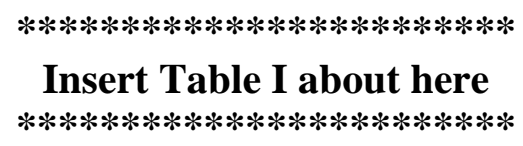

\section{Measurement of Variables}

All of the measures used to capture data for the empirical analyses were sourced from previously administered questionnaires used earlier by Björkman et al. (2007), Collings, Demirbag, Mellahi and Tatoglu, (2010), Fey et al. (2000), Fey and Björkman (2001), and Minbaeva et al. (2003).

The subsidiary type (DC MNE subsidiary, Turkish MNE subsidiary and indigenous firm) was treated as the dependent variable. 
The independent variables were measured as follows:

Employee training was computed by two items including the number of days of formal training managerial and non-managerial employees receive annually (Björkman et al. 2007; Minbaeva et al., 2003).

Competence-based performance appraisal was calculated by a composite index of three items drawing on the research instrument used by Minbaeva et al. (2003). The first item measures the percentage of the employees that regularly receive a formal evaluation of their performance, the second item measures the percentage of jobs where a formal job analysis has been conducted, and the final item measures the percentage of new jobs for which a formal analysis of the desired personal skills/competencies/characteristics is undertaken prior to making a selection decision.

Performance-based compensation was measured by four items used earlier by Björkman et al. (2007) and Minbaeva et al. (2003). Based on a five-point scale (ranging from $1=$ not at all to 5 = to a large extent) the first two items ask the respondents if the subsidiary uses performancebased compensation and to what extent their compensation systems are closely tied to the financial results of the subsidiary. The third item captures whether pay is linked to individual performance, and the final item identifies the extent to which differences in pay across employees in the subsidiary represent differences in their contribution to the subsidiary.

Employee empowerment was measured by an index composed of three items drawn from Collings et al. (2010). Using five-point scale items ( $1=$ not at all to $5=$ to a large extent), the first two items measure the extent to which employee input and suggestions are highly encouraged, and are often implemented, while the third item measures whether employees' capabilities are viewed as the subsidiary's main source of competitive advantage.

HRM and strategy fit was measured through an index comprising of three five-point scales ( $1=$ not at all to $5=$ to a large extent) adapted from Björkman et al. (2007) and Collings et al. (2010). The following questions were asked to respondents: (i) to what extent does their subsidiary make an explicit effort to align business and HRM/personnel strategies? (ii) to what 
extent is the HRM/personnel department involved in the strategic planning process? (iii) to what extent are HRM/personnel managers viewed by those outside the function as partners in the management of the business and agents for change?

Internal communication is defined as the extent to which exchange of information occurs within the firm and was measured by a scale including three items using five-point scales ( $1=$ not at all to 5 = to a large extent). The items initially used by Björkman et al. (2007) and Minbaeva et al. (2003) denote communication flows between (i) employees in different departments, (ii) nonmanagerial employees and managerial employees, and (iii) the HRM department and the top management team.

The existence of talent management practices was measured by a dichotomous variable where a value of 1 was assigned for the existence of talent management practices and 0 otherwise.

Subsidiary-level effects were captured by the following two control variables which included subsidiary size and industry sector.

Subsidiary size was measured as the logarithm of the total number of employees in the subsidiary.

To control for industry variations, industry dummies were created for five industry categories: (1) automotive, electronics and electrical equipment; (2) food, textiles, leather and paper; (3) financial services and engineering; (4) trade and hospitality, and (5) other services.

\section{Validity and Reliability of Measures}

The reliability and validity of constructs were assessed by confirmatory factor analysis (CFA) using AMOS. The CFA technique is based on the comparison of variance-covariance matrix obtained from the sample to the one obtained from the model. The technique is quite sensitive to sample size, and it is recommended to have several cases per free parameter (Bollen, 1989).

The measurement model comprising of six latent constructs and their respective observed variables showed an acceptable fit $\left[\chi^{2} /\right.$ d.f. $=2.26$; CFI $=.92 ;$ IFI $=.92 ;$ RMSEA $\left.=.06\right]$. All the 
observed variables had a standardized loading of more than .50 attesting the convergent validity of the measures. The internal consistency of the scales was measured using the Cronbach's alpha. Table II shows the Cronbach alpha coefficient for each construct. The reliability coefficients of six constructs ranged between .86 and .69 and are well above the acceptable level suggested by Nunnally (1978).

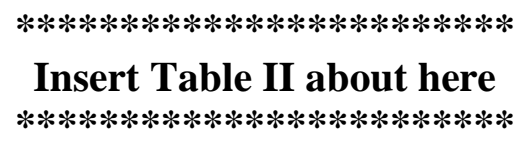

\section{Results}

The correlation matrix of the independent variables in the study is shown in Table III. The pairwise correlations do not seem to present serious multicollinearity problems for the multivariate analysis, as none of the variables have correlation coefficients above .40. Wetherill (1986) recommends an analysis of VIF when three or more variables are involved. In the near dependency the correlations between relevant pairs of variables need not be large (Wetherill, 1986). This is where VIF may play an important role and should not be larger than 10. Since the highest VIF value for independent variables was significantly lower than this cut-off point, multicollinearity in the explanatory variables for the data set does not seem to be a problem.

\section{$* * * * * * * * * * * * * * * * * * * * * * * *$}

\section{Insert Table III about here}

$* * * * * * * * * * * * * * * * * * * * * * * *$

Due to the categorical nature of the dependent variable and its inherent flexibility of not relying on strict measures of multivariate normality and equal variance-covariance matrices across groups (Hair, Black, Babin, Anderson, \& Tatham, 2006), a binary logistic regression procedure was preferred over other alternative techniques (e.g. discriminant analysis and MANOVA) in testing our two-part Hypotheses 1 (H1a and H1b), 2 (H2a and H2b) and 3 (H3a and H3b). The binary logistic model has been utilized frequently in studies on international HRM research (e.g. Brewster, Sparrow, \& Harris, 2005; Geary \& Roche, 2001; Gooderham, Parry, \& Ringdal, 2008; Walsh, 2001; Zheng, Morrison, \& O’Neill, 2006), and can be expressed as: 


$$
P(Y \mathrm{i}=1)=1 /[1+\exp (-a-X \mathrm{i} B)]
$$

Where Yi is the dependent variable, defined by a dummy variable either 1 or 0 . The value of 1 denotes the probability of an event occurring rather than another as shown by the value of 0 . $X \mathrm{i}$ is the vector of independent variables for $i$ th observation, $a$ is the intercept parameter, $B$ is the vector of the regression parameters (Amemiya, 1981). The regression coefficients estimate the impact of the independent variables on the probability of an event that occurs. A positive sign for the coefficient means that the variable increases the probability of the event occurring, a negative sign signifies the opposite. The maximum likelihood estimates of the parameters were obtained employing logistic regression. To exemplify, a positive sign on the independent variable coefficients indicates the likelihood of the higher level of emphasis placed on the use of HPWS by DC MNE subsidiaries in Turkey, while a negative sign indicates that of the higher level of emphasis by subsidiaries of Turkish MNEs.

In testing the study's hypotheses, three separate comparisons are made to investigate the extent to which the relative importance of HPWS varies between subsidiary types in Turkey: (1) comparing DC MNE subsidiaries located in Turkey to subsidiaries of Turkish MNEs in Turkey; (2) comparing DC MNE subsidiaries to indigenous firms in Turkey, and (3) comparing subsidiaries of Turkish MNEs to indigenous firms in Turkey. Three sets of coefficients are estimated and reported in Table IV.

The choice between DC MNE subsidiaries and Turkish MNE subsidiaries is presented in Model 1, where a value of zero is assigned for the latter group of subsidiaries as the base mode. Model 2 indicates the choice between DC MNE subsidiaries and indigenous firms, where indigenous firms are taken as the base. Finally, the choice between Turkish MNE subsidiaries and indigenous firms is presented in Model 3, where indigenous firms are identified as the base and given a zero value. 
Table IV shows that all three sets of models (Models 1 to 3 ) have high overall explanatory power with significant chi-square values $\left(\chi^{2}=27.54 ; \chi^{2}=75.85 ; \chi^{2}=66.86\right.$ at $p<.01$, respectively). All the models have a good fit with classification rates ranging from 77 percent to 66 percent of the observations, rates that are higher than would be expected by chance. The specificity (i.e., ability to correctly predict the subsidiary type denoted by 0 ) of the three models ranges from 88 percent to 56 percent, while their sensitivity (i.e., capacity to correctly predict subsidiary type denoted by 1) ranges from 74 percent to 60 percent. Pseudo R-square measures confirm that the models have adequate explanatory power.

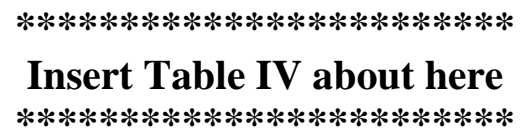

There is some partial support for H1a. The coefficients of employee training $(\beta=.008)$ and talent management $(\beta=.439)$ are positive and significant in both Model $1(p<.1)$ and Model $2(\beta$ $=.007, p<.1 ; \beta=0.583, p<.05)$ respectively, suggesting that the adoption level of employee training and talent management which constitute the two dimensions of "knowledge skills and abilities" component of HPWS is more likely to be higher in DC MNE subsidiaries located in Turkey than that in both local subsidiaries of Turkish MNEs and indigenous firms in Turkey.

No support, however, is found for H1b. The coefficients of both employee training $(\beta=$ .002 ) and talent management $(\beta=.264)$ are not significant in Model 3 , indicating that no significant variation exits between local subsidiaries of Turkish MNEs and indigenous firms in Turkey with respect to the adoption level of these two dimensions of "knowledge skills and abilities” component of HPWS.

The coefficient of competence-based performance appraisal is positive and significant in Models $1(\beta=2.43, p<.01)$ and $2(\beta=3.403, p<.01)$, while the sign on performance-based compensation is positive in both models but significant in only Model $1(\beta=.313, p<.1)$, providing a good level of support for H2a. This finding tends to confirm the view that the 
adoption level of competence-based performance appraisal and performance-based compensation which comprise the two dimensions of "motivation and effort" component of HPWS is more likely to be higher in DC MNE subsidiaries located in Turkey than that in both local subsidiaries of Turkish MNEs and indigenous firms in Turkey.

No support is found for H2b. The coefficients of both competence-based performance appraisal $(\beta=-.162)$ and performance-based compensation $(\beta=-.388)$ are negative but significant only for performance-based compensation $(p<.05)$ as shown in Model 3. This finding is somehow contrary to our expectation that the adoption level of "motivation and effort" component of HPWS is more likely to be higher in local subsidiaries of Turkish MNEs than in indigenous firms in Turkey.

Partial support is found for $\mathrm{H3a}$ in that two of the three dimensions (i.e., employee empowerment and HRM and strategy fit) which constitute the "opportunities to contribute" component of HPWS have positive and significant coefficients in Model $3(\beta=.496$ at $p<.05$ and $\beta=.830$ at $p<.01$, respectively), whereas the coefficients of all three dimensions are not found to be significant, as shown in Model 1. This finding indicates that the adoption level of “opportunities to contribute” component of HPWS is only found to be higher in local subsidiaries of Turkish MNEs than in indigenous firms in Turkey. No variation, however, is found between local subsidiaries of Turkish MNEs and DC MNE subsidiaries located in Turkey regarding the adoption level of “opportunities to contribute” component of HPWS.

Some support is found for H3b. Two of the three dimensions of the "opportunities to contribute” component of HPWS (i.e., employee empowerment and HRM and strategy fit) have positive and significant coefficients in Model $2(\beta=.539$ at $p<.05$ and $\beta=.413$ at $p<.05$, respectively). This finding tends to support the view that DC MNE subsidiaries located in Turkey are more likely to use the "opportunities to contribute" dimensions of HPWS than indigenous firms in Turkey.

Of the control variables, the subsidiary size has negative and significant coefficient $(\beta=$ .281 at $p<.01)$ in Model 1 , while it has positive and significant coefficient $(\beta=.663$ at $p<.01)$ 
in Model 3. The industrial dummies, with the exception of industrial category of food, textiles, leather and paper, have no significant effects. The coefficient of food, textiles, leather and paper is significant and negative in Models 2 and $3(\beta=-1.416, \beta=-1.567$ at $p<.01)$.

A summary of the degree of support for the study's hypotheses is shown in Table V.

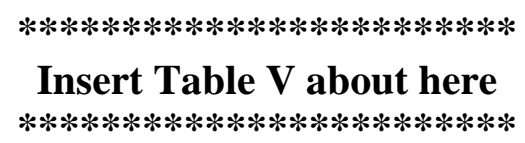

To further investigate whether there exist differences within the subsidiaries of the DC MNE category regarding the adoption level of HPWS dimensions, the overall sample of DC MNE subsidiaries were partitioned into two groups based on the broad country of origin ${ }^{2}$. The first group consists of subsidiaries established by MNEs from the USA and the UK and the second group includes subsidiaries established by continental European MNEs. The sample was partitioned, therefore, according to the relatively similar business orientations of the firms in each group of countries stemming mainly from political, institutional and cultural factors. While the notion of HPWS was originated in the USA and has been widely acknowledged across the world, the underlying characteristics of continental European countries are different from the USA and the UK. Differences in national and organizational cultures, a greater role of the state, and different forms of corporate governance have all led to variations in HPWS practices across these two groups of countries (Brewster, 2007).

The level of emphasis on HPWS by the broad country of origin of DC MNE subsidiaries is shown in Table VI. Based on the mean measure of the adoption level of HPWS dimensions, the subsidiaries established by the USA and UK MNEs indicate a higher level of adoption than those formed by continental European MNEs on four of the following HPWS dimensions: employee training, competence-based performance appraisal, employee empowerment, and HRM and strategy fit. In contrast, for the remaining three of the HPWS dimensions (i.e., performance-based compensation, internal communication, and talent management), the subsidiaries established by 
continental European MNEs are noted to have a higher level of adoption than those formed by the USA and UK MNEs. These findings suggest that the USA and UK MNEs emphasize fit: staff well trained in their jobs, operating in an empowered way within the overall strategy, whereas those from continental Europe are interested in developing staff more broadly and ensuring information is widely disseminated through the organization with staff rewarded on performance.

The test results however show that level of emphasis on each of the seven HPWS by DC MNE subsidiaries located in Turkey does not vary significantly with the broad country of origin of the DC MNEs. On this basis, it appears reasonable to argue that the implementation level of HPWS is independent of the nationality of the DC MNE subsidiaries in the Turkish context.

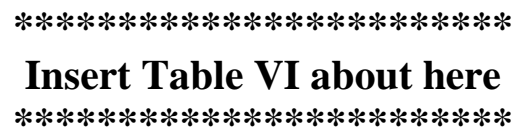

\section{Discussion and Conclusion}

This article has examined HPWS in three different sets of organizational contexts in Turkey. We suggest HPWS are likely to be utilized by MNEs in their subsidiaries as this is an important component of the firms' internationalization strategy. We also note that global markets and varied institutional environments encourage both DC MNEs and EC MNEs to have a configuration of HPWS which includes the three key components, "knowledge, skills and abilities”, "motivation and effort” and "opportunities to contribute”. However, we also caution that since the notion of HPWS is based on an Anglo-American model of management we are less sure how HPWS will be applied in other contexts. One argument we examine here using HPWS as a lens is whether as EC MNEs and DC MNEs become more global, the differences between them will narrow.

Our research has found partial support for the idea that the adoption level of employee training and talent management is higher in DC MNE subsidiaries located in Turkey than that in both local subsidiaries of Turkish MNEs and indigenous firms in Turkey. Yet we find no significant variation exists between local subsidiaries of Turkish MNEs and indigenous firms in Turkey with respect to the adoption level of HPWS. It appears that DC MNEs are indeed 
investing in staff to upskill them as part of their HRM strategy even if there may be little internal pressure to adopt them. We may be seeing here a country of origin effect as subsidiaries may be expected to conform to country-of-origin HRM systems and philosophies that sit closely with the wider institutional structures in the country where the HQ is located. If this is the case, HRM practices can therefore be different from those of similar organizations within the same sector in the host country, instead resembling those of similar firms in the home country or in other overseas subsidiaries (Marchington \& Wilkinson, 2012).

However the fact that we could find no variation between local subsidiaries of Turkish MNEs and indigenous firms in Turkey suggests that while training and development may well be an important part of Turkish MNEs' internationalization strategy they may lack resources to develop down this road, or are taking a different, perhaps a lower, road path. Indeed we suggest that EC MNES may not have the same resources as DC MNES and may therefore decide to take more of a cost advantage approach in relation to managing people.

We note that competence-based performance appraisal and performance-based compensation are higher in DC MNE subsidiaries located in Turkey than in both local subsidiaries of Turkish MNEs and indigenous firms in Turkey. We also find the adoption of "motivation and effort" components of HPWS is no higher in local subsidiaries of Turkish MNEs than in indigenous firms in Turkey. This suggests that DC MNEs may well be required to have more individual models of measurement of performance. Further, these home country factors may fit in within the broader corporate strategy of hard control while those organizations closer to the local culture, whether MNEs or indigenous, are less comfortable with such individualistic perspectives because of the more collectivist Turkish culture (Wasti, 1998).

The adoption level of "opportunities to contribute" component of HPWS is found to be higher in local subsidiaries of Turkish MNEs than in indigenous firms in Turkey. No variation, however, is noted between local subsidiaries of Turkish MNEs and DC MNE subsidiaries located in Turkey regarding this component of HPWS. It appears that while DC MNEs focus on transferring hard components of their HPWS to their subsidiaries, EC MNEs put more focus on 
the soft components of their HPWS. This fits with Girod et al.'s (2009) suggestion that an EC MNE's strength lies in expertise in utilizing soft capabilities. DC MNEs may have strong systems of control which constrain opportunities to contribute while local firms may simply operate from a more traditional or autocratic style which limits empowerment for rather different reasons.

\section{Managerial Implications}

The abundant management literature focusing on HPWS suggests that there are superior ways of conducting HRM that can be learned from market leaders and then transplanted into other environments. However, this fails to take into account cultural or institutional contexts or the specific characteristics of the individual organization (Pudelko, 2005). Furthermore, it tends to assume all employers use labor as part of a strategy for competitive advantage. However, this may not make sense for all organizations; HPWS is expensive to introduce and maintain and is only one route to competitive advantage. Some organizations might sensibly opt for lower labor costs and work with the grain of local working conditions (Marchington \& Wilkinson, 2012). What matters more are the HRM practices chosen to fit with the overall strategy, and that managers are equipped to deal with the practices put in place. Clearly introducing empowerment makes little sense if managers are not trained and cannot cope with the new style. Equally expensive programs of training and development may not be worthwhile if the job requirements are limited. Organizations need to ensure that their strategies, resources and line managers are in alignment and that mixed signals are not given. The debates about high road and low road and HPWS may look very different from the top of the organization (even more from the perspective of another country) than at the grassroots where strategy can be replaced by muddling through and managers are in daily wrestles accommodating local cultures.

However, the influence of home country and host country effects is neither straightforward nor static. For example, the importance of the subsidiary to the MNE as a whole is critical as it is much less likely that HQ will try to force specific HRM practices upon an establishment which is essential to future commercial success and that has the power to resist change (Geppert \& 
Williams, 2006). As Pulignano (2006, p. 513) notes, "space (is) opened up by company-specific organisational features ... to establish and pursue their group interests, but this is mediated by the institutional effects of the host country environments” (see Marchington \& Wilkinson, 2012).

Overall this paper makes a number of contributions. Firstly, it suggests that despite a view that business and HRM systems are converging due to the role of MNEs and the diffusion of management ideas and fashion, convergence remains a chimera. Second, whilst much has been written about western owned MNEs, there is less empirical evidence about new and EC MNEs and here we can see them taking a different path to both DC MNEs and indigenous firms. We also need to note the role of agency via the strategic choices made by managers even if this choice is shaped by factors external and internal to the organization.

\section{Limitations and Suggestions for Future Research}

A caution should be exercised when interpreting the results. Perhaps the most serious limitation of this study is its focus on a single host country setting. Our classification of MNEs into developed and emerging countries may also be too crude to assess the effect of internationalization on adoption level of HPWS. In fact, the international business literature provides several ways to measure a firm's degree of internationalization ranging from macro variables such as FDI or trade, to firm level variables (e.g. value number of countries in which the MNE operates or its value of foreign assets). Despite this, it has also been acknowledged that none of these measures really gauge a firm's degree of internationalization, as the degree of internationalization is a multifaceted concept and thus there is no unique or correct index (IettoGillies, 2009). While we focus on internationalization's effect on adoption level of HPWS by examining some variation among this broad categorization of country groups, it would be useful to further investigate a more fine-grained distinction between various countries with respect to the adoption level of HPWS. The collection of data from a single respondent in a subsidiary might be a cause for possible response bias, so it would be much more desirable to have multiple organizational respondents rather than relying on single respondents. Another limitation of this 
study is related to its cross-sectional nature. Future research that analyzes changes over time in the extent of HPWS adoption would enhance understanding of the impact of institutional changes on HRM practices. The study should be regarded as an exploratory one and be used as a basis for further research with relatively larger data sets.

Mehmet Demirbag is a professor of international business and head of the Department of Strategy and Organization in the Strathclyde Business School at the University of Strathclyde. His current research interest focuses on MNEs from emerging markets, offshore research and development activities of MNEs, and the impact of institutional factors on MNEs' operations. He has authored/co-authored more than 60 articles on these topics published in journals such as the Journal of Management Studies, Human Resource Management, the Journal of World Business, Management International Review, and International Business Review, among others. He coguest-edited seven journal special issues, including Human Resource Management, the Journal of World Business, International Business Review, and International Marketing Review on emerging markets and emerging market MNEs. He is also co-editor of two books and numerous book chapters.

Ekrem Tatoglu is a professor of International Business and also serves the Chair of International Trade and Business at Bahcesehir University, Istanbul, Turkey. He has a wide experience of research and teaching in International Business and International Strategic Management at undergraduate, postgraduate and executive levels. His research interests include global management strategies, FDI in emerging countries and international entry mode strategies. He published over 70 scholarly articles in various internationally refereed journals including Management International Review, International Journal of Human Resource Management, Journal of World Business, International Business Review and International Small Business Journal amongst others. He also co-authored a book entitled Dimensions of Western Foreign Direct Investment in Turkey published by Quorum Books. Professor Tatoglu is editor of Afro Eurasian Studies published by MUSIAD - Independent Industrialists' and Businessmen's Association, Istanbul, Turkey and also area editor of the Journal of Knowledge-Based Organizations published by the Information Resources Management Association. He also serves as editorial advisory board member of the Employee Relations published by Emerald Group Publishing.

Adrian Wilkinson is a professor and the director of the Centre for Work, Organisation and Wellbeing at Griffith University in Australia. Prior to his 2006 appointment, he worked at Loughborough University in the United Kingdom, where he was a professor of human resource management. He holds visiting professorships at Loughborough University, Sheffield University, and the University of Durham, and is an academic fellow at the Centre for International Human Resource Management at the Judge Institute of the University of Cambridge. Wilkinson has written/edited 20 books, more than 150 articles in refereed journals, and numerous book chapters. In 2011, he was elected as an academician of the Academy of Social Sciences in recognition of his contribution to the field. In 2012, he was shortlisted by HR Magazine for the HR Most Influential International Thinker award. 


\section{References}

Amemiya, T. (1981). Qualitative response models: A survey. Journal of Economic Literature, 19, 1483-1536.

Armstrong, J.S., \& Overton, T.S. (1977). Estimating non-response bias in mail surveys. Journal of Marketing Research, 14(3), 396-402.

Arthur, J.B. (1994). Effects of human resource systems on manufacturing performance and turnover. Academy of Management Journal, 37, 670-687.

Aycan, Z. (2006). Human resource management in Turkey. In P. Budhwar, \& K. Mellahi (Eds.), Human resources management in the Middle East (pp. 160-179). London, UK: Routledge.

Aycan, Z., \& Fikret-Pasa, S. (2000). Leadership preferences, career choices and work motivation in Turkey: A national profile and regional differences. Paper presented at $15^{\text {th }}$ International Congress of the International Association of Cross-Cultural Psychology, USA.

Bae, J., \& Lawler, J.J. (2000). Organizational and HRM strategies in Korea: Impact on firm performance in an emerging economy. Academy of Management Journal, 43(3), 502-517.

Barney, J.B. (1991). Firm resources and sustained competitive advantage. Journal of Management, 17, 99-120.

Barry M., \& Wilkinson, A. (2011). The Research Handbook of comparative employment relations. Cheltenham, UK: Edward Elgar.

Bartlett, C.A., \& Ghoshal, S. (1986). Tap your subsidiaries for global reach. Harvard Business Review, 4(6), 87-94.

Bartlett, C.A., \& Ghoshal, S. (1988). Creation, adoption and diffusion of innovations by subsidiaries of multinational corporations. Journal of International Business Studies, 19(3), 365-388.

Bartlett, K.R., Lawler, J.J., Bae, J., Chen, S-J., \& Wan, D. (2002). Differences in international human resource development among indigenous firms and multinational affiliates in east and southeast Asia. Human Resource Development Quarterly, 13(4), 383-405.

Becker, B., \& Gerhart, B. (1996). The impact of human resource management on organizational performance: Progress and prospects. Academy of Management Journal, 39(4), 779-801.

Becker, B., \& Huselid, M. (2009). Strategic human resources management: Where do we go from here? In A. Wilkinson, N. Bacon, T. Redman, \& S. Snell (Eds.), The Sage handbook of human resource management, London, UK: Sage. 
Björkman, I., Fey, C.F., \& Park, H.J. (2007). Institutional theory and MNC subsidiary HRM practices: Evidence from a three country study. Journal of International Business Studies, 38, 430-445.

Bollen, K.A. (1989). Structural equations with latent variables. New York: Wiley.

Boxall, P., \& Macky, K. (2009). Research and theory on high-performance work systems: Progressing the high involvement stream. Human Resource Management Journal, 19(1), 323.

Brewster, C. (2007). Comparative HRM: European views and perspectives. International Journal of Human Resource Management, 18, 769-787.

Brewster, C., Sparrow, P., \& Harris, H. (2005). Towards a new model of globalizing HRM. International Journal of Human Resource Management, 16(6), 949-970.

Chang, Y.Y., Mellahi, K., \& Wilkinson, A. (2009). Control of subsidiaries of MNCs from emerging economies: The case of Taiwanese MNCs in the UK. International Journal of Human Resource Management, 20(1), 75-95.

Chang, Y.Y., Wilkinson, A., \& Mellahi, K. (2007). HRM strategies and MNCs from emerging economies in the UK. European Business Review, 19(5), 404-419.

Chen, S-J., Lawler, J.J., \& Bae, J. (2005). Convergence in human resource systems: A comparison of locally owned and MNC subsidiaries in Taiwan. Human Resource Management, 44(3), 237-256.

Chittoor, R., Sarkar, M.B., Ray, S., \& Aulakh, P.S. (2009). Third-world copycats to emerging multinationals: Institutional changes and organizational transformation in the Indian pharmaceutical industry. Organization Science, 20(1), 187-205.

Collings, D., Demirbag, M., Mellahi, K., \& Tatoglu, E. (2010). Strategic orientation, human resource management practices and organizational outcomes: Evidence from Turkey. International Journal of Human Resource Management, 21(4), 2589-2613.

Collings, D.G., Lavelle, J., \& Gunnigle, P. (2011). The role of MNEs. In A. Wilkinson, \& M. Barry (Eds.) Handbook on comparative employment relations (pp. 402-420). Cheltenham, UK: Edward Elgar Press.

Delery, J.E., \& Doty, D.H. (1996). Models of theorizing in strategic human resource management: Tests of universalistic, contingency, and configurational performance predictions. Academy of Management Journal, 39, 802-835.

Demirbag, M., Mirza, H., \& Weir, D. (1995). Dynamics of manufacturing joint ventures in Turkey and the role of industrial groups. Management International Review, 35(Special Issue 1), 35-51. 
Demirbag, M., Tatoglu, E., \& Glaister, K.W. (2009). Equity-based entry modes of emerging country multinationals: Lessons from Turkey. Journal of World Business, 44(4), 445-462.

Demirbag, M., Tatoglu, E., \& Glaister, K.W. (2010). Institutional and transaction cost determinants of Turkish MNEs' location choice. International Marketing Review, 27(3), 272-294.

Demirbag, M., Collings, D.G., Tatoglu, E., Mellahi, K., \& Wood, G. (2014). High-performance work systems and organizational performance in emerging economies: Evidence from MNEs in Turkey. Management International Review, 54(3), 325-359.

DiMaggio, P.J., \& Powell, W.W. (1983). The iron cage revisited: Institutionalism and collective rationality in organizational fields. American Sociological Review, 48, 147-160.

Dyer, L., \& Reeves, T. (1995). Human resource strategies and firm performance: What do we know, and where do we need to go? International Journal of Human Resource Management, 6, 657-667.

Engardio, P., Arndt, M., \& Geri, S. (2006). Emerging giants. Business Week, New York, July 31.

Ercek, M. (2006). HRMization in Turkey: Expanding the rhetoric-reality debate in space and time. International Journal of Human Resource Management, 17(4), 648-672.

Fenton-O'Creevy, M.P., Gooderham, P.M., \& Nordhaug, O. (2008). Human resource management in US subsidiaries in Europe and Australia: centralization or autonomy? Journal of International Business Studies, 39(1), 151-166.

Fenton-O'Creevy, M.P., \& Wood, S.J. (2007). Diffusion of human resource management systems in UK headquartered multinational enterprises: Integrating institutional and strategic choice explanations. European Journal of International Management, 1(4), 329349.

Fey, C.F., \& Björkman, I. (2001). The effect of human resource management practices on MNC subsidiary performance in Russia. Journal of International Business Studies, 32(1), 59-75.

Fey, C.F., Björkman, I., \& Pavlovskaya, A. (2000). The effect of human resource management practice on firm performance in Russia. International Journal of Human Resource Management, 11(1), 1-18.

Fikret-Pasa, S., Kabasakal, H., \& Bodur, M. (2001). Society, organizations, and leadership in Turkey. Applied Psychology: An International Review, 50, 559-589.

Geary, J.F., \& Roche, W.K. (2001). Multinationals and human resource practices in Ireland: A rejection of the 'new conformance thesis'. International Journal of Human Resource Management, 12(1), 109-127. 
Geppert, M., \& Williams, K. (2006). Global national and local practices in multinational corporations: Towards a socio-political framework. International Journal of Human Resource Management, 17(1), 49-69.

GDFI (General Directorate of Foreign Investment) (2011). Foreign investment report, Ankara.

Girod, S.J.G., Belin, J.B., \& Thomas, R.J. (2009). Are emerging market multinationals creating the global models for the future? Accenture Institute for High Performance.

Glaister, K., Dincer, O., Tatoglu, E., \& Demirbag, M. (2009). A comparison of strategic planning practices in companies from the UK and Turkey. Journal of Management Development, 28(4), 361-379.

Glover, L., \& Wilkinson, A. (2007). Worlds colliding: The transition of modern management practices with a UK based subsidiary of a Korean owned company. International Journal of Human Resource Management, 18(8), 1437-1455.

Goksen, N.S., \& Usdiken, B. (2001). Uniformity and diversity in Turkish business groups: Effects of scale and time of founding. British Journal of Management, 12(4), 325-340.

Gooderham, P., Nordhaug, O., \& Ringdal, K. (1998). When in Rome, do they do as Romans: HRM practices of US subsidiaries in Europe. Management International Review, 38(special issue), 47-64.

Gooderham, P., Parry, E., \& Ringdal, K. (2008). The impact of bundles of strategic human resource management practices on the performance of European firms. International Journal of Human Resource Management, 19(11), 2041-2056.

Greenwood, M.R. (2002). Ethics and HRM: A review and conceptual analysis. Journal of Business Ethics, 36(3), 261-278.

Guest, D. (2011). Human resource management and performance: Still searching for some answers. Human Resource Management Journal, 21(1), 3-13.

Guillen, M.F., \& Garcia-Canal, E. (2009). The American model of the multinational firm and the "New" multinationals from emerging economies. Academy of Management Perspectives, 23(2), 23-35.

Gupta, A.K., \& Govindarajan, V. (2000). Knowledge flows within multinational corporations. Strategic Management Journal, 21, 473-496.

Gunduz, L., \& Tatoglu, E. (2003). A comparison of the financial characteristics of group affiliated and independent firms in Turkey. European Business Review, 15(1), 48-54.

Guthrie, J.P. (2001). High-involvement work practices, turnover and productivity: Evidence from New Zealand. Academy of Management Journal, 44(1), 180-190. 
Guthrie, J.P., Liu, W., Flood, P.C., \& MacCurtain, S. (2008). High performance work systems, workforce productivity, and innovation: A comparison of MNCs and indigenous firms. Link working paper series (paper no. 04-08). Dublin City University, Ireland: The Learning, Innovation and Knowledge Research Centre.

Hair, J.F., Black, W.C., Babin, B.J., Anderson, R.E., \& Tatham, R.L. (2006). Multivariate data analysis. New Jersey: Prentice Hall.

Hall, P.A., \& Soskice, D. (2001). An introduction to varieties of capitalism. In P.A. Hall, \& D. Soskice (Eds.), Varieties of capitalism: The institutional foundations of comparative advantage (pp. 1-68). Oxford, UK: Oxford University Press.

Hofstede, G. (1980). Culture’s consequences: International differences in work related values. London, UK: Sage.

House, R.J., Hanges, P.J., Javidan, M., Dorfman, P.W., \& Gupta, V. (2004). Culture, leadership and organizations: The globe study of 62 societies. Thousand Oaks, CA: Sage.

Huselid, M.A. (1995). The impact of human resource management practices on turnover, productivity and corporate financial performance. Academy of Management Journal, 38, 635-672.

Huselid, M.A., Jackson, S.E., \& Schuler, R.S. (1997). Technical and strategic human resource management effectiveness as determinants of firm performance. Academy of Management Journal, 40, 171-188.

Ietto-Gillies, G. (2009). Conceptual issues behind the assessment of the degree of internationalization. Transnational Corporations, 18(3), 59-83.

Invest in Turkey (2012). Investment guide, retrieved from http://www.invest.gov.tr/enUS/Pages/Home.aspx

Iseri-Say, A., Toker, A., \& Kantur, D. (2008). Do popular management techniques improve performance? Evidence from large businesses in Turkey. Journal of Management Development, 27(7), 660-677.

Jensen, J.M., Patel, P.C., \& Messersmith, J.G. (2011). High-performance work systems and job control: Consequences for anxiety, role overload and turnover intensions. Journal of Management, 39(6), 1699-1724.

Jensen, R., \& Szulanski, G. (2004). Stickiness and the adaptation of organizational practices in cross-border knowledge transfers. Journal of International Business Studies, 35(6), 508523.

Kabasakal, H., \& Bodur, M. (2002). Arabic cluster: A bridge between east and west. Journal of World Business, 37, 40-54.

Kale, P., Singh, H., \& Raman, A.P. (2009). Don’t integrate your acquisitions, partner them. Harvard Business Review, December, 109-115. 
Kerr, C., Dunlop, J.T., Harbison, F.H., \& Myers, C.A. (1960). Industrialism and industrial man. London, UK: Heinemann.

Khavul, S., Benson, G.S. \& Datta, D. (2010). Is internationalization associated with investments in HRM? A study of entrepreneurial firms in emerging markets. Human Resource Management, 49(4), 693-713.

Kidger, P.J. (1991). The emergence of international human resource management. International Journal of Human Resource Management, 2(2), 149-163.

Kostova, T., \& Roth, K. (2002). Adoption of an organizational practice by subsidiaries of multinational corporations: Institutional and relational effects. Academy of Management Journal, 45(1), 215-233.

Kostova, T., Roth, K., \& Dacin, T. (2008). Institutional theory in the study of MNCs: A critique and new directions. Academy of Management Review, 33(4), 994-1006.

Lawler, E.E. (1986). High-Involvement management. Participative strategies for improving organizational performance. San Francisco, CA: Jossey-Bass Inc.

Legge, K. (2005). Human resource management: Rhetorics and realities. Basingstoke, UK: Palgrave Macmillan.

Lepak, D.P., Liao, H., Chung, Y., \& Harden, E.E. (2006). A conceptual review of human resource management system in strategic human resource management research. In J.J. Martocchio (Ed.), Research in personnel and human resource management review, Vol. 25 (pp. 217-271). Bingley, UK: Emerald Group Publishing.

Lessard, D., \& Lucea, R. (2009). Mexican multinationals: Insights from CEMEX. In R. Ramaurti, \& J.V. Singh (Eds.), Emerging multinationals in emerging markets, (pp. 280311). Cambridge, UK: Cambridge University Press.

Levitt, T. (1983). The globalization of the markets. Harvard Business Review, 3, 92-102.

Luo, Y., \& Tung, R.L. (2007). International expansion of emerging market enterprises: A springboard perspective. Journal of International Business Studies, 38(4), 481-498.

Luo, Y., Sun, J., \& Wang, S.L. (2011). Emerging economy copycats: Capability, environment and strategy. Academy of Management Perspectives, 25(2), 37-56.

Madhok, A., \& Keyhani, M. (2012) Acquisitions as entrepreneurship: Asymmetries, opportunities, and the internationalization of multinationals from emerging economies. Global Strategy Journal, 2, 26-40.

Mäkelä, K., \& Brewster, C. (2009). Interunit interaction contexts, interpersonal social capital, and the differing levels of knowledge sharing. Human Resource Management, 48(4), 591-613. 
Marchington, M., \& Wilkinson, A. (2012). Human Resource Management at Work (5 ${ }^{\text {th }}$ ed.). London, UK: Chartered Institute of Personnel and Development.

McGaughey, S., \& De Cieri, H. (1999). Reassessment of convergence and divergence dynamics: Implications for international HRM. International Journal of Human Resource Management, 10(2), 235-250.

McGuinness, M., Demirbag, M., \& Bandara, S. (2013). Towards a multi-perspective model of reverse knowledge transfer in multinational enterprises: A case study of Coats plc. European Management Journal, 31(2), 179-195.

Mellahi, K., Demirbag, M., Collings, D.G., Tatoglu, E., \& Hughes, M. (2013). Similarly different: A comparison of HRM practice in MNE subsidiaries and local firms in Turkey. International Journal of Human Resource Management, 24(12), 2339-2368.

Minbaeva, D., Pedersen, T., Björkman, I., Fey, C.F., \& Park, H.J. (2003). MNC knowledge transfer, subsidiary absorptive capacity, and HRM. Journal of International Business Studies, 34, 586-599.

Minbaeva, D.B. (2008). HRM practices affecting extrinsic and intrinsic motivation of knowledge receivers and their effect on intra-MNC knowledge transfer. International Business Review, 17, 703-713.

Morris, S., \& Snell, S.A. (2011). Intellectual capital configurations and organizational capability: An empirical examination of human resource subunits in the multinational enterprise. Journal of International Business Studies, 42, 805-827.

Nunnally, J.C. (1978). Psychometric theory (2nd ed.). New York: McGraw-Hill.

Pfeffer, J. (1998). The human equation: Building profits by putting people first. Boston: Harvard Business School Press.

Pudelko, M. (2005). Continuity vs. change: The key dilemma for Japanese management. In R. Haak, \& M. Pudelko (Eds.), Japanese management: The search for a new balance between continuity and change. New York: Palgrave.

Pudelko, M., \& Harzing, A.W. (2007). Country-of-origin, localization, or dominance effect? An empirical investigation of HRM practices in foreign subsidiaries. Human Resource Management, 46(4), 535-559.

Pulignano, V. (2006). The diffusion of employment practices of US-based multinationals in Europe: A case study comparison of British- and Italian-based subsidiaries. British Journal of Industrial Relations, 44(3), 497-518.

Ramamurti, R. (2012). What is really different about emerging market multinationals. Global Strategy Journal, 2, 41-47. 
Rosenzweig, P.M., \& Nohria, N. (1994). Influences on human resource management practices in multinational corporations. Journal of International Business Studies, 25, 229-242.

Rowley, C., \& Benson, J. (2002). Convergence and divergence in Asian human resource management. California Management Review, 44(2), 90-109.

Sahadev, S., \& Demirbag, M. (2011). Convergence and divergence in employment practices in the emerging economies of Europe: Assessing the impact of foreign ownership and European integration. Human Resource Management Journal, 21(4), 395-414.

Sayim, K.Z. (2011). Policy transfer from advanced to less-advanced institutional environments: Labor market orientations of US MNEs in Turkey. Human Relations, 64(4), 573-597.

Schuler, R., Dowling, P., \& De Cieri, H. (1993). An integrative framework of strategic international human resource management. International Journal of Human Resource Management, 1, 717-764.

Smith, C., \& Meiksins, P. (1995). System, society and dominance effects in cross-national organizational analysis. Work Employment and Society, 9, 241-267.

Strauss, G., \& Hanson, M. (1997). Review article: American anti-management theories of organization: A critique of paradigm proliferation. Human Relations, 50: 1426-1429.

Szulanski, G. (1996). Exploring internal stickiness: Impediments to the transfer of best practice within the firm. Strategic Management Journal, 17, 27-44.

Tanova, C., \& Nadiri, H. (2005). Recruitment and training policies and practices: The case of Turkey as an EU candidate. Journal of European Industrial Training, 29, 694-711.

Taylor, S., Beechler, S., \& Napier, N. (1996). Toward an integrative model of strategic international human resource management. Academy of Management Review, 21(4), 959985.

Thite, M., Wilkinson, A., \& Shah, D. (2012). Internationalization and HRM strategies across subsidiaries in multinational corporations from emerging economies: A conceptual framework. Journal of World Business, 47(2), 251-258.

Tregaskis, O., \& Brewster, C. (2006), Converging or diverging? A comparative analysis of trends in contingent employment practice in Europe over a decade. Journal of International Business Studies, 37(1), 111-126.

Tregaskis, O., Daniels, K., Glover, L., Butler, P., \& Meyer, M. (2013). High performance work practices and firm performance: A longitudinal case study. British Journal of Management, 24(2), 225-244.

UNCTAD (2011). World Investment Report 2008, New York: United Nations. 
Usdiken, B., \& Wasti, A.S. (2002). Turkiye’de akademik bir inceleme alani olarak personel veya “insan kaynaklari” yonetimi. Amme Idaresi Dergisi, 35(3), 1-37.

Walsh, J. (2001). Human resource management in foreign-owned workplaces: Evidence from Australia. International Journal of Human Resource Management, 12(3), 425-444.

Wasti, S.A. (1998). Cultural barriers in the transferability of Japanese and American human resources practices to developing countries: The Turkish case. International Journal of Human Resource Management, 9(4), 608-631.

Wetherill, G.B. (1986). Regression analysis with applications. London, UK: Chapman \& Hall

Whitley, R. (2000). Divergent capitalisms: The social structuring and change of business systems. Oxford, UK: Oxford University Press.

Wilkinson, A., Wood, G., \& Deeg, R (Eds.) (2014). The Oxford handbook of employment relations: Comparative employment systems. Oxford: Oxford University Press.

Wilkinson, A., Wood, G., \& Demirbag, M. (2014). People management and emerging market multinationals. Human Resource Management, 53(6).

Wood, S., \& de Menezes, L. (1998). High commitment management in the UK: Evidence from the workplace industrial relations survey and employers' manpower and skills practice survey. Human Relations, 51, 485-517.

Wood, G., \& Lane, C. (2012). Institutions, change and diversity. In C. Lane, \& G. Wood (Eds.), Capitalist diversity and diversity within capitalism. London, UK: Routledge.

Wright, P.M., \& Bosewell, W.R. (2002). Desegregating HRM: A review and synthesis of micro and macro human resource management research. Journal of Management, 28(3), 247-276.

Zacharatos, A., Barling, J., \& Iverson, R.D. (2005). High-performance work systems and occupational safety. Journal of Applied Psychology, 90, 77-84.

Zheng, C., Morrison, M., \& O'Neill, G. (2006). An empirical study of high performance HRM practices in Chinese SMEs. International Journal of Human Resource Management, 17(10), 1772-1803. 


\section{High Performance Work Systems}

Knowledge, skills and abilities

- Employee training

- Talent management

Motivation and effort

- Competence-based performance appraisal

- Performance-based compensation

Opportunities to contribute

- Employee empowerment

- HRM and strategy fit

- Internal communication

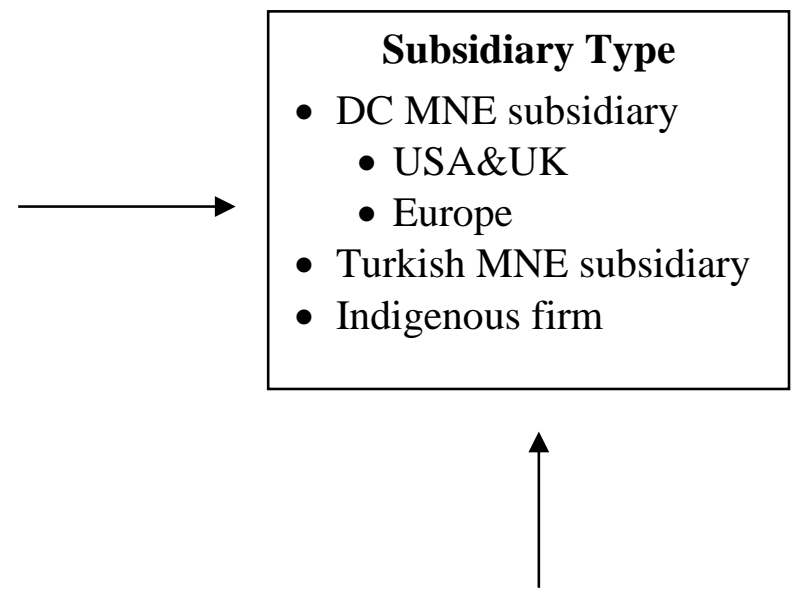

Control Variables

- Subsidiary size

- Industry groupings

FIGURE 1. Research Framework 
TABLE I. Characteristics of Questionnaire Respondent Firms

\begin{tabular}{|l|c|c|c|c|c|c|c|c|c|}
\hline \multirow{2}{*}{ Characteristics } & \multicolumn{2}{|c|}{$\begin{array}{c}\text { Overall } \\
\text { sample }\end{array}$} & \multicolumn{2}{c|}{$\begin{array}{c}\text { DC MNE } \\
\text { subsidiaries }\end{array}$} & \multicolumn{2}{c|}{$\begin{array}{c}\text { Turkish MNE } \\
\text { subsidiaries }\end{array}$} & \multicolumn{2}{c|}{$\begin{array}{c}\text { Indigenous } \\
\text { firms }\end{array}$} \\
\cline { 2 - 11 } & $\mathbf{N}$ & $\mathbf{\%}$ & $\mathbf{N}$ & $\mathbf{\%}$ & $\mathbf{N}$ & $\mathbf{\%}$ & & $\mathbf{N}$ & $\mathbf{\%}$ \\
\hline Industry of subsidiary & & & & & & & & \\
\hline Automotive, electronics and electrical eq. & 47 & 13.8 & 17 & 16.2 & 12 & 14.5 & 18 & 11.8 \\
\hline Food, textiles, leather and paper & 82 & 24.1 & 11 & 10.4 & 13 & 15.6 & 58 & 37.9 \\
\hline Other manufacturing & 31 & 9.1 & 9 & 8.6 & 9 & 10.9 & 13 & 8.5 \\
\hline Financial services and engineering & 55 & 16.1 & 21 & 20.0 & 15 & 18.0 & 19 & 12.4 \\
\hline Trade and hospitality & 71 & 20.8 & 30 & 28.6 & 17 & 20.5 & 24 & 15.7 \\
\hline Other services & 55 & 16.1 & 17 & 16.2 & 17 & 20.5 & 21 & 13.7 \\
\hline Subsidiary size (number of employees) & & & & & & & & \\
\hline Small size (Less than 50) & 8 & 2.3 & 4 & 3.8 & 1 & 1.2 & 3 & 1.9 \\
\hline Medium size (50-249) & 156 & 45.7 & 43 & 40.9 & 25 & 30.1 & 88 & 57.5 \\
\hline Large size (Equal or more than 250) & 177 & 51.9 & 58 & 55.3 & 57 & 68.7 & 62 & 40.6 \\
\hline Subsidiary age (years) & & & & & & & & \\
\hline Young firms (Less than 10) & 69 & 20.2 & 30 & 28.5 & 5 & 6.0 & 34 & 22.2 \\
\hline Middle age firms (10 to 19) & 116 & 34.0 & 24 & 22.9 & 40 & 48.2 & 52 & 34.0 \\
\hline Mature firms (More than 20) & 156 & 45.8 & 51 & 48.6 & 38 & 45.8 & 67 & 43.8 \\
\hline Respondent type & & & & & & & & \\
\hline General/deputy general manager & 87 & 25.5 & 21 & 20.0 & 15 & 18.1 & 51 & 33.3 \\
\hline HRM manager & 155 & 45.5 & 51 & 48.6 & 44 & 53.0 & 60 & 39.3 \\
\hline Planning manager & 50 & 14.7 & 14 & 13.3 & 15 & 18.1 & 21 & 13.7 \\
\hline Other senior managers & 49 & 14.3 & 19 & 18.1 & 9 & 10.1 & 21 & 13.7 \\
\hline & $\mathbf{3 4 1}$ & & $\mathbf{1 0 5}$ & & $\mathbf{8 3}$ & & $\mathbf{1 5 3}$ \\
\hline
\end{tabular}


TABLE II. Measurement Model Validation - Confirmatory Factor Analysis Results

\begin{tabular}{|c|c|c|}
\hline Constructs/Observed Variables & $\begin{array}{c}\text { Standardized } \\
\text { loadings }\end{array}$ & $\begin{array}{c}\text { Cronbach } \\
\text { alpha }\end{array}$ \\
\hline Employee training & & .86 \\
\hline Number of days of formal training managerial employees receives annually. & .74 & \\
\hline Number of days of formal training non-managerial employees receives annually. & .67 & \\
\hline Competence-based performance appraisal & & .80 \\
\hline $\begin{array}{l}\text { Proportion of the employees that regularly receive a formal evaluation of their } \\
\text { performance (in per cent). }\end{array}$ & .70 & \\
\hline Proportion of jobs where a formal job analysis has been conducted (in per cent). & .90 & \\
\hline $\begin{array}{l}\text { Proportion of new jobs for which a formal analysis of the desired personal } \\
\text { skills/competencies/characteristics is carried out prior to making a selection } \\
\text { decision (in per cent). }\end{array}$ & .68 & \\
\hline Performance-based compensation & & .70 \\
\hline The extent to which subsidiary uses performance-based compensation. & .54 & \\
\hline $\begin{array}{l}\text { The extent to which compensation system is closely connected with the financial } \\
\text { results of the subsidiary. }\end{array}$ & .82 & \\
\hline The extent to which pay is tied to individual performance & .52 & \\
\hline $\begin{array}{l}\text { The extent to which differences in pay across employees in the subsidiary } \\
\text { represent differences in their contribution to the subsidiary. }\end{array}$ & .69 & \\
\hline Employee empowerment & & .69 \\
\hline The extent to which employee input and suggestions are highly encouraged. & .58 & \\
\hline The extent to which employee input and suggestions are often implemented. & .65 & \\
\hline $\begin{array}{l}\text { The extent to which employees' capabilities are viewed as the subsidiary's main } \\
\text { source of competitive advantage. }\end{array}$ & .72 & \\
\hline HRM and strategy fit & & .82 \\
\hline $\begin{array}{l}\text { The extent to which the subsidiary makes an explicit effort to align business and } \\
\text { HR/personnel strategies. }\end{array}$ & .83 & \\
\hline $\begin{array}{l}\text { The extent to which the HR/personnel department is involved in the strategic } \\
\text { planning process. }\end{array}$ & .87 & \\
\hline $\begin{array}{l}\text { The extent to which HR/personnel managers are viewed by those outside the } \\
\text { function as partners in the management of the business and agents for change. }\end{array}$ & .64 & \\
\hline Internal communication & & .73 \\
\hline $\begin{array}{l}\text { The extent to which communication flows well between employees in different } \\
\text { departments. }\end{array}$ & .76 & \\
\hline $\begin{array}{l}\text { The extent to which communication flows well between non-managerial } \\
\text { employees and managerial employees. }\end{array}$ & .79 & \\
\hline $\begin{array}{l}\text { The extent to which communication between the HR department and the top } \\
\text { management team is effective. }\end{array}$ & .52 & \\
\hline
\end{tabular}

Chi-square/df $=2.26$, CFI $=.92, \mathrm{IFI}=.92, \mathrm{RMSEA}=.06$. 
TABLE III. Descriptive Statistics and Correlation Coefficients of Variables

\begin{tabular}{|c|c|c|c|c|c|c|c|c|c|c|c|c|c|c|c|}
\hline Variables & Mean & SD & 1 & 2 & 3 & 4 & 5 & 6 & 7 & 8 & 9 & 10 & 11 & 12 & 13 \\
\hline 1. Employee training & 32.19 & 33.24 & 1.00 & & & & & & & & & & & & \\
\hline 2. Competence-based performance appraisal & 69 & .26 & -.05 & 1.00 & & & & & & & & & & & \\
\hline 3. Performance-based compensation & 3.53 & .80 & .13 & $.19 *$ & 1.00 & & & & & & & & & & \\
\hline 4. Employee empowerment & 3.74 & .66 & -.01 & .14 & $.35 *$ & 1.00 & & & & & & & & & \\
\hline 5. HRM and strategy fit & 3.83 & .83 & .03 & $.29 *$ & $.32 *$ & $.33 *$ & 1.00 & & & & & & & & \\
\hline 6. Internal communication & 4.03 & .63 & -.01 & .13 & .15 & $.40 *$ & $.29 *$ & 1.00 & & & & & & & \\
\hline 7. Talent management & .41 & .49 & .12 & $.23^{*}$ & $.26^{*}$ & $.18^{*}$ & $.28 *$ & .11 & 1.00 & & & & & & \\
\hline 8. Logarithm of firm size & 5.80 & 1.49 & -.05 & .16 & .02 & .03 & $.26^{*}$ & .00 & .11 & 1.00 & & & & & \\
\hline 9. Automotive, electronics and electrical eq. & .14 & .34 & .00 & -.00 & .05 & .00 & .07 & .06 & .13 & -.04 & 1.00 & & & & \\
\hline 10. Food, textiles, leather and paper & .24 & .42 & -.03 & -.09 & -.03 & .06 & -.03 & -.07 & -.10 & -.13 & $-.22 *$ & 1.00 & & & \\
\hline 11. Financial services and engineering & .16 & .36 & .01 & .10 & .03 & -.03 & .07 & .04 & .02 & .11 & -.17 & $-.24 *$ & 1.00 & & \\
\hline 12. Trade and hospitality & .21 & .40 & .03 & -.01 & -.07 & -.05 & -.08 & .01 & .01 & .01 & $-.20 *$ & $-.28 *$ & $-.22 *$ & 1.00 & \\
\hline 13. Other services & .16 & .36 & .06 & .02 & .05 & -.02 & -.04 & .06 & -.04 & $-.18 *$ & -.17 & $-.24 *$ & $-.19 *$ & $-.22 *$ & 1.00 \\
\hline
\end{tabular}

\section{Notes:}

$* p<.01$

$\mathrm{N}=341$ 
TABLE IV. Logistic Regression Results for Subsidiary Type and HPWS

\begin{tabular}{|c|c|c|c|c|c|c|}
\hline \multirow[b]{3}{*}{ Variables } & \multicolumn{2}{|c|}{ Model 1} & \multicolumn{2}{|c|}{ Model 2} & \multicolumn{2}{|c|}{ Model 3} \\
\hline & \multicolumn{2}{|c|}{$\begin{array}{l}\text { DC MNE Subsidiary vs. } \\
\text { Turkish MNE Subsidiary } \\
\text { (DC MNE Subsidiary = 1) }\end{array}$} & \multicolumn{2}{|c|}{$\begin{array}{l}\text { DC MNE Subsidiary vs. } \\
\text { Indigenous Firm } \\
\text { (DC MNE Subsidiary = 1) }\end{array}$} & \multicolumn{2}{|c|}{$\begin{array}{l}\text { Turkish MNE Subsidiary vs. } \\
\text { Indigenous Firm } \\
\text { (Turkish MNE Subsidiary = 1) }\end{array}$} \\
\hline & Coefficient & Wald statistic & Coefficient & Wald statistic & Coefficient & Wald statistic \\
\hline \multicolumn{7}{|l|}{ Independent variables } \\
\hline Employee training & $.008 *$ & 1.836 & $.007 *$ & 1.710 & -.002 & .006 \\
\hline Talent management & $.439 *$ & 1.417 & $.583 * *$ & 2.763 & .264 & .452 \\
\hline Competence-based performance appraisal & $2.430 * * *$ & 9.013 & $3.403 * * *$ & 17.427 & -.162 & .051 \\
\hline Performance-based compensation & $.313^{*}$ & 1.557 & .074 & .082 & $-.388 * *$ & 2.268 \\
\hline Employee empowerment & .024 & .006 & $.539 * *$ & 2.653 & $.496 * *$ & 2.382 \\
\hline HRM and strategy fit & -.219 & .501 & $.413 * *$ & 2.678 & $.830 * * *$ & 7.925 \\
\hline Internal communication & -.247 & .532 & -.219 & .494 & -.153 & .206 \\
\hline \multicolumn{7}{|l|}{ Control variables } \\
\hline Logarithm of firm size & $-.281 * * *$ & 5.885 & .141 & 1.128 & $.663^{* * *}$ & 12.456 \\
\hline Automotive, electronics and electrical equipments & -.199 & .080 & -.184 & .065 & -.534 & .558 \\
\hline Food, textiles, leather and paper & .029 & .002 & $-1.416 * * *$ & 4.941 & $-1.567 * * *$ & 6.018 \\
\hline Financial services and engineering & .660 & .987 & .133 & .038 & -.448 & .375 \\
\hline Trade and hospitality & .516 & .671 & .370 & .321 & -.098 & .022 \\
\hline Other services & .034 & .003 & -.164 & .062 & -.430 & .417 \\
\hline Intercept & .031 & .000 & $-6.590 * * *$ & 14.069 & $-6.784 * * *$ & 15.179 \\
\hline \multicolumn{7}{|l|}{ Reliability } \\
\hline Model chi-square & \multicolumn{2}{|c|}{$27.54 * * *$} & \multicolumn{2}{|c|}{$75.85 * * *$} & \multicolumn{2}{|c|}{$66.86 * * *$} \\
\hline Sensitivity & \multicolumn{2}{|c|}{.74} & \multicolumn{2}{|c|}{.66} & \multicolumn{2}{|c|}{.60} \\
\hline Specificity & \multicolumn{2}{|c|}{.56} & \multicolumn{2}{|c|}{.83} & \multicolumn{2}{|c|}{.88} \\
\hline Correct ratio & \multicolumn{2}{|c|}{.66} & \multicolumn{2}{|c|}{.76} & \multicolumn{2}{|c|}{.77} \\
\hline Proportional chance criterion & \multicolumn{2}{|c|}{.50} & \multicolumn{2}{|c|}{.52} & \multicolumn{2}{|c|}{.55} \\
\hline Cox \& Snell R square & \multicolumn{2}{|c|}{.16} & \multicolumn{2}{|c|}{.30} & \multicolumn{2}{|c|}{.28} \\
\hline Nagelkerke R square & \multicolumn{2}{|c|}{.22} & \multicolumn{2}{|c|}{.41} & \multicolumn{2}{|c|}{.39} \\
\hline
\end{tabular}

Notes:

${ }^{*} p<.1 ; * * p<.05 ; * * * p<.01$

$\mathrm{N}=341$; DC MNE subsidiaries = 105; Turkish MNE subsidiaries = 83; Indigenous firms = 153 
Table V. Summary of Support for the Study's Hypotheses

\begin{tabular}{|l|c|}
\hline Hypothesis & Degree of support \\
\hline $\begin{array}{l}\text { Hypothesis 1a: The adoption level of "knowledge, skills and } \\
\text { abilities" component of HPWS will be higher in DC MNE } \\
\text { subsidiaries located in Turkey than that in both local subsidiaries of } \\
\text { Turkish MNEs and indigenous firms in Turkey. }\end{array}$ & Partially supported \\
\hline $\begin{array}{l}\text { Hypothesis 1b: The adoption level of "knowledge, skills and } \\
\text { abilities" component of HPWS will be higher in local subsidiaries } \\
\text { of Turkish MNEs than in indigenous firms in Turkey. }\end{array}$ & Not supported \\
\hline $\begin{array}{l}\text { Hypothesis 2a: The adoption level of "motivation and effort” } \\
\text { component of HPWS will be higher in DC MNE subsidiaries } \\
\text { located in Turkey than that in both local subsidiaries of Turkish } \\
\text { MNEs and indigenous firms in Turkey. }\end{array}$ & Supported \\
\hline $\begin{array}{l}\text { Hypothesis 2b: The adoption level of “motivation and effort” } \\
\text { component of HPWS will be higher in local subsidiaries of } \\
\text { Turkish MNEs than in indigenous firms in Turkey. }\end{array}$ & Not supported \\
\hline $\begin{array}{l}\text { Hypothesis 3a: The adoption level of “opportunities to contribute” } \\
\text { component of HPWS will be higher in local subsidiaries of Turkish } \\
\text { MNEs than that in both subsidiaries of DC MNEs and indigenous } \\
\text { firms in Turkey. }\end{array}$ & Partially supported \\
\hline $\begin{array}{l}\text { Hypothesis } 3 b: \text { The adoption level of "opportunities to contribute” } \\
\text { component of HPWS will be higher in subsidiaries of DC MNEs } \\
\text { than in indigenous firms in Turkey. }\end{array}$ & Supported \\
\hline
\end{tabular}


TABLE VI. HPWS and Broad Country of Origin of DC MNE Subsidiaries

\begin{tabular}{lcccc}
\hline High Performance Work Systems $^{\dagger}$ & Group & Mean & SD $^{\dagger \dagger}$ & t-value \\
\hline \multirow{2}{*}{ Employee training } & USA \& UK & 40.01 & 57.40 & \\
& EUROPE & 34.87 & 26.62 & .55 \\
\hline \multirow{2}{*}{ Competence-based performance appraisal } & USA \& UK & .84 & .19 & \multirow{2}{*}{.81} \\
\hline \multirow{2}{*}{ Performance-based compensation } & EUROPE & .80 & .22 & .75 \\
& USA \& UK & 3.65 & .75 \\
\multirow{2}{*}{ Employee empowerment } & EUROPE & 3.83 & .74 & -1.22 \\
\hline \multirow{2}{*}{ HRM and strategy fit } & USA \& UK & 3.90 & .71 & \\
& EUROPE & 3.81 & .69 & .58 \\
\hline \multirow{2}{*}{ Internal communication } & USA \& UK & 4.14 & .79 & \multirow{2}{*}{.38} \\
\hline \multirow{2}{*}{$N=96$} & EUROPE & 4.08 & .84 & \\
\hline
\end{tabular}

Notes:

${ }^{\dagger}$ Due to categorical nature of the variables of talent management and broad country of origin of DC MNE subsidiaries, the association between these two variables was measured by the chi-square test of independence. The test results indicated no significant association between the two variables $\left(\chi^{2}=2.69, p=.11\right)$.

${ }^{{ }^{\dagger \dagger} \mathrm{SD}}=$ standard deviation. 
${ }^{1}$ We would like to thank the editor and two anonymous reviewers for their insightful comments on earlier versions of this paper.

${ }^{2}$ We are grateful to one of the anonymous reviewers for this helpful advice for clarifying the conceptualization regarding the effect of country of origin on HRM practices related to our HPWS measures. 